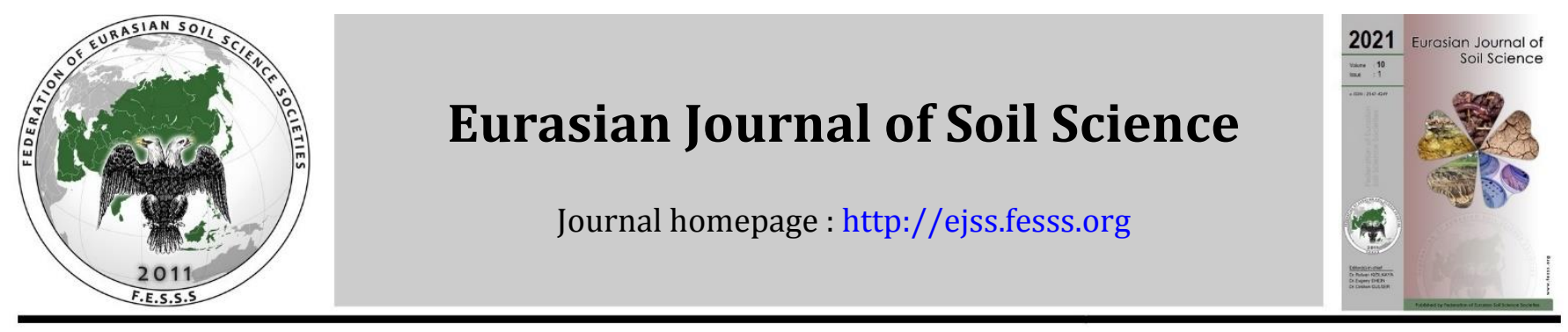

\title{
Fluoride contamination in wetlands of Kuttanad, India: Predisposing edaphic factors
}

\section{Vasanthakumari Roshni a, Variampally Sankar Harikumar b,*}

a Research and Development Centre, Bharathiar University, Coimbatore-641 046, Tamil Nadu. India

b Department of Post Graduate Studies and Research in Botany, Sanatana Dharma College (University of Kerala), Alappuzha-688 003, Kerala, India

\section{Article Info}

Received : 15.04 .2020

Accepted : 14.10 .2020

Available online : 21.09 .2020

\section{Author(s)}

V.Roshni

V.S. Harikumar *

* Corresponding author

\begin{abstract}
Fluoride contamination has now become an emerging concern in agroecosystems. A diagnostic survey was conducted across the fluoride $\left(\mathrm{F}^{-}\right)$ contaminated wetlands of Kuttanad, India with an aim to examine the influence of edaphic factors on $\mathrm{F}^{-}$concentration in soils. The soils (Inceptisols) predominantly sandy had a substantial percentage of clay and the soil characteristics such as bulk density (BD), moisture, temperature, $\mathrm{pH}$, electrical conductivity (EC), cation exchange capacity (CEC) and organic carbon (OC) varied with soils. Similarly, the soil nutrients (NPK) and the oxides of Fe and Al as well as total sesquioxide differed with soils. Principal component analysis (PCA) revealed that the first two components (PC1 and PC2) significantly explained the variability existed in the data while the third component (PC3) did not explain any variation compared to the first two components. PC1, PC2 and PC3 accounted for $52.2 \%, 12.7 \%$ and $11.3 \%$ of the variation in the profiles respectively. Out of soil samples, $53 \%$ had a similar distribution of soil characteristics and F- concentration and are grouped together in PC1 while, the remaining $47 \%$ of the samples had a similar distribution of characteristics and are grouped together in PC2. Among the soil characteristics examined, silt content, $\mathrm{pH}, \mathrm{EC}, \mathrm{CEC}, \mathrm{OC}, \mathrm{N}$ and $\mathrm{P}$ had a significant $(\mathrm{P}<0.001)$ positive association along PC1 indicating that these factors are contributing to the augmentation of $\mathrm{F}^{-}$concentration in the wetlands of Kuttanad.
\end{abstract}

Keywords: Fluoride contamination, wetland soil, edaphic factors.

(C) 2021 Federation of Eurasian Soil Science Societies. All rights reserved

\section{Introduction}

Fluorine is the most reactive electronegative anion in the halide series (Greenwood and Earnshaw, 1997). Like other halides, it is a monovalent ion which has a strong affinity to combine chemically with other elements to form compounds called fluorides (F-). Fluorides are ubiquitous in nature, including water, soil and plants (Singh et al., 2018). Fluoride accounts for about 0.06-0.09\% of the Earth's crust (Koritnig, 1951). Major natural sources of F- are F- containing mineral rocks like fluorspar, rock phosphate, cryolite, apatite, mica etc. (Kinnunen et al., 2003). Application of F- containing phosphate fertilizers (Loganathan et al., 2001; Borah and Saikia, 2011), fumigants and pesticides (Tsai, 2010; Li et al., 2015), irrigation water (Pettenati et al., 2013; Bustingorri and Lavado, 2014) or by deposition of gaseous and particulate emission from industry (Ozsvath, 2009; Jayarathne et al., 2014; Fuge, 2019) are some of the anthropogenic sources contributing to the elevated concentration of $\mathrm{F}$ - in soil.

It is well-known that F- is beneficial for humans and other animals in small quantities (Underwood, 1977; Adriano, 1986) as it is an essential element required for the integrity of teeth and bones (Jha et al., 2011). However, ingestion of elevated level of F-, has a harmful effect, causing dental and skeletal fluorosis in 
humans (Annadurai et al., 2014; Choubisa, 2018a; Kabir et al., 2019; Dharmaratne, 2019) and animals (Choubisa, 2018b; Panchal and Sheikh, 2017; Yuan et al., 2019). In plants elevated levels of F- exposure reduces germination, growth and productivity (Chakrabarti et al., 2013; Tyagi et al., 2017; Ahmed et al., 2019). Fortunately, the uptake of $F^{-}$by plants from the substrate is typically low because soil-borne F- most often occurs in a form unavailable to plants hence plants will absorb amounts of this element under natural conditions. However, in soils polluted in F-, uptake may take up its excessive quantities (Smolek et al., 2011) which affect crop production. Excessive $\mathrm{F}^{-}$in the soil is reported to have adverse effect on microbial communities (Ropelewska et al., 2016; Qiao et al., 2018; Lu et al., 2019) and can inhibit the activity of a variety of microbial enzymes (Telesiński et al., 2008; Mondal et al., 2015).

Kuttanad, the well-known granary is situated in Alappuzha District of Kerala State in south India. It is a unique tropical wetland agroecosystem where below sea level farming practice is being continued for more than a century (Kumar and Devadas, 2016) in 55,000 hectares of rice fields. High F- content in the sediments of Kuttanad waters has already been reported (Geetha et al., 2007) which is considered to be originated from dissolution of fluorapatite which is a common mineral in the Tertiary sediments of the area (Varma, 2017). Long residence time, sediment-groundwater interaction and facies changes ( $\mathrm{Ca}-\mathrm{HCO}_{3}$ to $\mathrm{Na}-\mathrm{HCO}_{3}$ ) during groundwater flow regime are pointed out as the major factors responsible for the high $\mathrm{F}$ - content in the groundwater of this area (Raj and Shaji, 2017). Besides this, Kuttanad being a major producer of rice for the state, to achieve high crop productivity targets, the farmers of this region are compelled to apply $\mathrm{F}$ bearing synthetic fertilizers and plant protection chemicals in large quantities which overburden the ecosystem with F- We presume that the edaphic factors could also have an influence on the F- concentration in soil. To test this hypothesis we have conducted a diagnostic survey across the F- contaminated areas of the Kuttanad wetlands with an aim to figure out the influencing edaphic factors which augment/alleviate the $\mathrm{F}$ concentration in soils.

\section{Material and Methods}

\section{Location and study area}

Kuttanad (289.39 $\mathrm{km}^{2}$ ) located within Alappuzha District in the west coast of Kerala State in India lies between latitude $9^{\circ} 35^{\prime} \mathrm{N}$ and longitude $76^{\circ} 40^{\prime} \mathrm{E}$ (Figure 1). It has a summit elevation of 2. $2 \mathrm{~m}$ bsl. Kuttanad has a tropical humid climate with intermittent dry and wet period. From the middle of May to the middle of November, the wet season prevails with both northeast and south-west monsoons. The rainfall pattern varies with season. The average rainy days are about 120 per year with a mean annual precipitation of $153.28 \mathrm{~mm}$. The mean annual temperature is $29^{\circ} \mathrm{C}$ and means relative humidity is $79 \%$. January and February are dry and cool months followed by summer from March to May. Kuttanad Below Sea-level Farming System (KBSFS) is unique as it is the only system in India where rice cultivation is practiced below sea level. The major land use structure within the area is flat stretches of rice fields in about 50,000 ha of mostly reclaimed delta swamps.

\section{Sampling scheme}

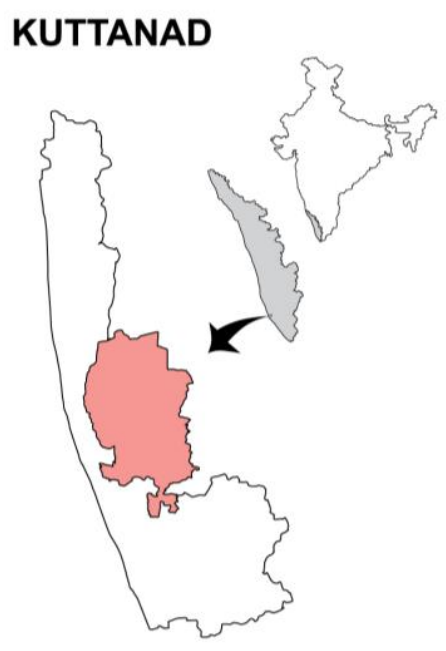

Soil samples were collected from 15 locations of Kuttanad rice fields during the fallow period (January) of 2016. Samples were withdrawn from a depth of $20 \mathrm{~cm}$ below the surface layer using a soil auger. Five replicate samples (ca $500 \mathrm{~g}$ ) taken from each location were collected in polythene bags, labeled and taken to the laboratory and stored at $4^{\circ} \mathrm{C}$ till analysis. All the soil samples taken were analyzed for soil characteristics and $\mathrm{F}^{-}$concentration.

\section{Evaluation of soil characteristics}

Texture analysis was done by determining the percentage of sand, silt and clay in the soil sample following the micro-pipette method (Miller and Miller, 1987). The bulk density (BD) was calculated as the ratio between the air-dried soil mass and the soil volume from the fresh soil. Temperature expressed in ${ }^{\circ} \mathrm{C}$ was gauged using a thermometer. Moisture content was determined within 2-3 $\mathrm{h}$ of sample collection by drying $10 \mathrm{~g}$ soil sample in a hot air oven $\left(105 \pm 1^{0} \mathrm{C}, 48 \mathrm{~h}\right)$. Gravimetric soil moisture was the difference in soil weights before and after drying (Gardner, 1986). The $\mathrm{pH}$ and electrical conductivity (EC) were measured in solution after placing $1 \mathrm{~g}$ of soil in $5 \mathrm{ml}$ of deionized water. The $\mathrm{pH}$ was determined with a digital $\mathrm{pH}$ meter 
(Systronics MK IV, Ahmedabad, India). EC of the soil expressed as $\mathrm{dSm}^{-1}$ was determined using Systronics 304 conductivity meter. Cation exchange capacity (CEC) was measured after saturating the soil with $1 \mathrm{~N}$ ammonium acetate $\left(\mathrm{NH}_{4} \mathrm{OAc}\right.$ ) and displacing it with $1 \mathrm{~N} \mathrm{NaOAc}$ (Chapman, 1965). For the measurement of organic carbon (OC), the method described by Islam and Weil (1998) was followed. Available nitrogen (N) in air-dried soil was determined by alkaline permanganate method (Subbaiah and Asija, 1956), phosphorus (P) by ascorbic acid method (Wantanabe and Olsen, 1965) and exchangeable potassium (K) was extracted in a $1 \mathrm{~N}$ neutral (pH 7.0) ammonium acetate solution and measured using Elico-CL345 (Elico, India) digital flame photometer (Stanford and English, 1949). Free oxides of iron (Fe) and aluminium (Al) in soil were detected by dithionate extraction method (Mehra and Jackson, 1960). One gram air-dried soil was mixed with $2 \mathrm{~g}$ sodium dithionate, $20 \mathrm{~g}$ sodium citrate and $50 \mathrm{ml}$ distilled water. After shaking the mixture overnight in a reciprocating shaker at $2000 \mathrm{rpm}$, the concentration of $\mathrm{Fe}$ and $\mathrm{Al}$ in the supernatant was measured at 248.3 $\mathrm{nm}$ and $309.3 \mathrm{~nm}$ respectively using Perkin Elmer-2380 Atomic absorption spectrophotometer. The elemental values were multiplied with the appropriate conversion factor $\mathrm{Fe}_{2} \mathrm{O}_{3}$ (1.43) and $\mathrm{Al}_{2} \mathrm{O}_{3}$ (1.89) to obtain their oxide values. The oxide values of $\mathrm{Fe}$ and $\mathrm{Al}$ were added to determine the total sesquioxides in soil. The sodium 2- (parasulphophenylazo)- 1, 8- dihydroxy- 3.6- naphthalene disulphonate (SPADNS) method was used to determine the F- content in soil (Baird et al., 2017). Briefly, $0.5 \mathrm{~g}$ of air-dried finely ground soil sample was digested with $5 \mathrm{ml}$ aqua regia for $45 \mathrm{~min}$ in a microwave digester. The digested sample was allowed to cool and then filtered through Whatman No 4 filter paper. The filterate was analyzed for F- using UV-Vis spectrophotometer (Systronics, India) at $570 \mathrm{~nm}$.

\section{Statistical analyses}

Descriptive statistical methods were used to explain soil characteristics. Principal component analysis (PCA) was applied to summarize correlation among treatment (location/soil characteristics) and variable (soil F-) using R software (R Core Team, 2019).

\section{Results and Discussion}

\section{Soil characteristics}

Wetland soils (Inceptisols) of Kuttanad were predominantly sandy with silt and clay fractions (Table 1). Sand, silt and clay content in the soils ranged from 11.10-65.0, 12.0-53.85 and 6.0-48.50\% respectively and the mean percentage were $39.17,30.37$ and $30.44 \%$ respectively. In an earlier study Thampatti and Jose (2000) reported that the incidence of same soil fractions in Kuttand wetlands, nevertheless, they could not find any definite pattern of distribution of sand, silt or clay in these soils.

Table 1. Descriptive statistical measurements of soil characteristics and F-concentration in wetlands of Kuttanad

\begin{tabular}{|c|c|c|c|c|}
\hline Variable & Min & Max & Mean & SD \\
\hline Sand (\%) & 11.10 & 65.00 & 39.17 & 15.18 \\
\hline Silt (\%) & 12.00 & 53.85 & 30.37 & 13.22 \\
\hline Clay (\%) & 6.00 & 48.50 & 30.44 & 12.54 \\
\hline $\mathrm{BD}\left(\mathrm{mg} \mathrm{m}^{-3}\right)$ & 0.50 & 1.80 & 1.14 & 0.19 \\
\hline Moisture (\%) & 4.20 & 13.90 & 8.87 & 2.93 \\
\hline Temperature $\left({ }^{\circ} \mathrm{C}\right)$ & 22.50 & 25.50 & 24.26 & 0.81 \\
\hline $\mathrm{pH}\left(1: 5 \mathrm{H}_{2} \mathrm{O}\right)$ & 3.40 & 4.80 & 4.23 & 0.32 \\
\hline $\mathrm{EC}\left(\mathrm{dS} \mathrm{m}^{-1}\right)$ & 0.35 & 1.52 & 1.03 & 0.29 \\
\hline $\mathrm{CEC}\left(\mathrm{cmol} \mathrm{kg}^{-1}\right)$ & 30.80 & 60.00 & 44.56 & 8.71 \\
\hline $\mathrm{OC}\left(\mathrm{g} \mathrm{kg}^{-1}\right)$ & 12.00 & 36.80 & 23.40 & 7.63 \\
\hline Available $\mathrm{N}\left(\mathrm{kg} \mathrm{h}^{-1}\right)$ & 275.70 & 502.95 & 397.68 & 80.57 \\
\hline Available $\mathrm{P}\left(\mathrm{kg} \mathrm{h}^{-1}\right)$ & 10.10 & 95.00 & 43.60 & 26.58 \\
\hline Available $\mathrm{K}\left(\mathrm{kg} \mathrm{h}^{-1}\right)$ & 46.50 & 383.20 & 169.66 & 112.72 \\
\hline $\mathrm{Fe}_{2} \mathrm{O}_{3}\left(\mathrm{mg} \mathrm{kg}^{-1}\right)$ & 1378.00 & 1431.00 & 1405.13 & 17.68 \\
\hline $\mathrm{Al}_{2} \mathrm{O}_{3}\left(\mathrm{mg} \mathrm{kg}^{-1}\right)$ & 222.50 & 356.10 & 282.43 & 35.65 \\
\hline Total sesquioxide $\left(\mathrm{mg} \mathrm{kg}^{-1}\right)$ & 1610.50 & 1787.00 & 1687.56 & 50.21 \\
\hline Total Fluoride $\left(\mathrm{mg} \mathrm{kg}^{-1}\right)$ & 5.88 & 37.77 & 25.88 & 7.29 \\
\hline
\end{tabular}

Soil compaction is a problem that affects agricultural productivity particularly in clayey soils (Nunes et al., 2015) as it affects root growth and distribution (Taylor and Brar, 1991). The values of BD in the present study varied from $0.50-1.80 \mathrm{mg} \mathrm{m}^{-3}$. None of the soils recorded a value beyond the critical limit suggesting that soil compaction is not an alarming issue in Kuttanad agroecosystem. Management of soils through tillage and related practices could be suggested as a reason for low soil compaction in these soils (Unger and Kaspar, 1994). 
The soils of Kuttanad encounter frequent changes associated with flooding and associated drying (Suganya and Sivapullaiah, 2015). The soils showed lower moisture content ranging from $4.20-13.90 \%$ possibly due to the fast drainage through the spore space (Easton and Bock, 2016).

The results showed that the mean temperature of the soil $\left(0-20 \mathrm{~cm}\right.$ depth) ranged from $22.50-25.50^{\circ} \mathrm{C}$ with an average of $24.26^{\circ} \mathrm{C}$ which was matching with the atmospheric temperature. This is in agreement with the finding of Beena (2005) that the soil temperature of Kuttanad region is isohyperthermic as the annual soil temperature at a depth of $50 \mathrm{~cm}$ is $22^{\circ} \mathrm{C}$. It is rather difficult to corroborate with a single reason for the existence of a soil temperature as observed in the present study because of the high heterogeneity and complexity of the relationships (Lehnert, 2014).

All the soils analyzed had an acidic range of $\mathrm{pH}$ (3.4-4.8) which is in congruence with the early reports from this region (Beena and Thampatti, 2013). Soil acidity is determined by a number of factors of which the nature of the parent material from which the soil is derived is the principal one (Owolabi et al., 2003). Oxidation of pyrite in soil to sulphuric acid by rainwater during wet season in Kuttanad soils is another reason for the $\mathrm{pH}$ to decrease (Mathew et al., 2001).

Saline water intrusion during summer months is an ecological phenomenon contributing to the increase of salinity in Kuttanad soils. The present study reports a value of EC ranging from $0.35-1.52 \mathrm{dSm}^{-1}$ which remained below the tolerable limit. This could be due to the flushing off/dilution of salts by rain water during monsoon season (Sarkar et al., 2019) or due to the movement of salts to the deeper soil profiles (Thampatti and Jose, 2000).

The CEC ranged from $30.80-60.00 \mathrm{cmol} \mathrm{kg}^{-1}$ in the soil samples. CEC is an important indicator of soil quality in agroecosystems (Khledian et al., 2017) as it represents soil's ability to hold positively charged ions (Saidi, 2012). The increase of clay fraction in the soil is reported to influence the CEC of soil (Khaledian et al., 2017). Soils in general had a high OC (>7.5 g kg-1) ranging from 12-36.80 $\mathrm{g} \mathrm{kg}^{-1}$ with a mean value of $23.40 \mathrm{~g} \mathrm{~kg}^{-1}$ which was reported in other studies (Thafna et al., 2017). The presence of sand layers, differential accumulation of organic matter and sedimentary nature of the parent materials are attributed to be the reason for heterogeneity in OC distribution (Thampatti and Jose, 2000). Incorporation of crop residues into soil after rice cropping in Kuttanad fields could be another possible reason for the increase in OC.

\section{Soil nutrient status}

Nitrogen is a nutrient being applied in greater quantities in crop production (Pyngrope et al., 2019) which is a common practice in Kuttanad also. Despite this, the soils showed an available $\mathrm{N}$ content ranging from 275.70-502.95 $\mathrm{kg} \mathrm{h}^{-1}$ which remained below the higher $\mathrm{N}$ availability class ( $\left.>560 \mathrm{~kg} \mathrm{~h}^{-1}\right)$. This contrasts the finding of Thafna et al. (2017) who observed a high $\mathrm{N}$ content $\left(771.91 \mathrm{~kg} \mathrm{~h}^{-1}\right)$ in Kuttnad soils. This is possibly due to an increased utilization of $\mathrm{N}$ by the previous crop (Guo et al., 2017). Losses through the mechanism such as high volatilization, denitrification, chemical and microbial fixation and runoff are suggested as other reasons for the reduction of $\mathrm{N}$ in soils (Kumar et al., 2014).

The soils of Kuttanad belonged to the higher $\left(>25 \mathrm{~kg} \mathrm{~h}^{-1}\right) \mathrm{P}$ availability class as it ranged from 10.10-95.0 kg $\mathrm{h}^{-1}$ with a mean $\mathrm{P}$ content of $43.60 \mathrm{~kg} \mathrm{~h}^{-1}$. It is an established fact that the rice crop utilizes only $25-30 \%$ of applied P. and the remaining part which is not readily available remain in soil (Gudadhe et al., 2015) which gradually increase as available $P$ over a period of time.

The available $\mathrm{K}$ content of the soils ranged from $46.50-383.20 \mathrm{~kg} \mathrm{~h}^{-1}$ which is in agreement with the earlier finding of Thafna et al. (2017) that the soils in this region had a high content of K. The increase in soil organic matter (Thafna et al., 2017), soil texture and irrigation regime are some of the reasons reported for the increase in $\mathrm{K}$ content in soil.

\section{Elemental oxides in soil}

Oxides of $\mathrm{Fe}$ and $\mathrm{Al}$ in the soils were in a range between $1378-1430$ and $224.10-355 \mathrm{mg} \mathrm{kg}^{-1}$ respectively and its total value (total sesquioxide) ranged between $1612-1785 \mathrm{mg} \mathrm{kg}^{-1}$. In the tropics, the oxides and hydroxides of $\mathrm{Fe}$ and $\mathrm{Al}$ otherwise known s sesquioxides form soil components of which a small proportion is present in the form of organic complexes (Lekwa and Whiteside, 1986). They are important parameters that influence some soil chemical reaction and properties (Ibia, 2005). Soils of Kuttanad differed in the quantity of sesquioxides they contain indicating that the parent material for the genesis of soils have undergone varied degree of weathering (Shaw and West, 2017). The maintenance of an acidic soil reaction might have triggered the distribution of more Fe and Al (Ebimol et al., 2017) to the soil which in turn reflected on sesquioxides.

\section{Fluoride concentration in soil}

Soil samples recorded a total F- concentration ranging between 5.88-37.77 $\mathrm{mg} \mathrm{kg}^{-1}$ with an average value of $25.88 \mathrm{mg} \mathrm{kg}^{-1}$ which was far above the normal value of $2.5 \mathrm{mg} \mathrm{kg}^{-1}$ reported from Indian soil (Naik et al., 
2017). The possible route of F- contamination in Kuttanad soils is mostly through the dissolution of fluorapatite which is a common mineral in the tertiary sediments of this area (Raj and Shaji, 2017). Longterm use of F- containing ground water to irrigate crop (Mondal, 2017), use of synthetic fertilizers, pesticides and other agricultural chemicals (Annadurai et al., 2014) are other possible routes of contamination in Kuttanad soils.

\section{Principal component analysis}

Influence of soil characteristics on F- concentration was evaluated by PCA. PC1 accounted for 52.2\%, the second component PC2 for $12.7 \%$ and the third component PC3 for $11.3 \%$ of the variation in the profiles (Table 2). The first two components could explain significant variability existed in the data $(\sim 65 \%)$ and the third component PC3 did not significantly explain the variance compared to the first two components. It was evident from the biplot (Figure 2) that the soils 1, 3, 5, 6, 10, 12, 13 and 14 had a similar distribution of soil characteristics and F- concentration and are grouped together in PC1 while, the soils 2, 4, 7, 8, 9, 11 and 15 had a similar distribution of soil characteristics and are grouped together in PC2. Among the soil characteristics, soil silt content, $\mathrm{pH}, \mathrm{EC}, \mathrm{CEC}, \mathrm{OC}$, available $\mathrm{N}$ and $\mathrm{P}$ had a significant $(\mathrm{P}<0.001)$ positive association along PC1 whereas, $\mathrm{BD}$, extractable $\mathrm{K}, \mathrm{Al}_{2} \mathrm{O}_{3}, \mathrm{Fe}_{2} \mathrm{O}_{3}$ and total sesquioxide had negative association with PC1. The variables clay content and temperature had a significant positive association along PC2. The soil sand content however exhibited negative association along PC2. Previous studies also corroborate our finding on the factors influencing F- concentration in soil (Skjelkvåle, 1994; Xie et al., 2008). The study therefore warrants the need of a concern of these factors in the mitigation strategies of $\mathrm{F}$ - in wetland soils.

Table 2. Loadings on the principal components

\begin{tabular}{|c|c|c|c|}
\hline \multirow{2}{*}{ Measurements } & \multicolumn{3}{|c|}{ Principal components } \\
\hline & PC1 & PC2 & PC3 \\
\hline Eigen value & 8.88 & 2.16 & 1.93 \\
\hline Percentage variance & 52.20 & 12.70 & 11.30 \\
\hline Proportion & 0.52 & 0.13 & 0.11 \\
\hline Sand & -0.187 & $-0.834 a$ & -0.375 \\
\hline Silt & $0.516 \mathrm{a}$ & 0.291 & 0.495 \\
\hline Clay & -0.317 & $0.701 \mathrm{a}$ & -0.067 \\
\hline Moisture & $-0.342 a$ & 0.057 & $-0.591 a$ \\
\hline Soil Temp & 0.008 & $0.667 a$ & -0.135 \\
\hline $\mathrm{BD}$ & $-0.531 a$ & -0.118 & $0.717 \mathrm{a}$ \\
\hline $\mathrm{pH}$ & $0.572 \mathrm{a}$ & -0.343 & 0.568 \\
\hline $\mathrm{EC}$ & $0.904 a$ & -0.020 & -0.094 \\
\hline CEC & $0.894 a$ & 0.067 & -0.120 \\
\hline $\mathrm{OC}$ & $0.674 a$ & 0.482 & -0.017 \\
\hline Av.N & $0.850 \mathrm{a}$ & 0.032 & 0.278 \\
\hline Av.P & $0.930 \mathrm{a}$ & -0.207 & 0.043 \\
\hline Av.K & $-0.800 a$ & -0.040 & 0.367 \\
\hline $\mathrm{Fe}_{2} \mathrm{O}_{3}$ & $-0.871 a$ & -0.043 & -0.116 \\
\hline $\mathrm{Al}_{2} \mathrm{O}_{3}$ & $-0.940 a$ & 0.129 & 0.099 \\
\hline Total Sesquioxide & $-0.973 a$ & 0.077 & 0.030 \\
\hline Total Fluoride & $0.927 \mathrm{a}$ & -0.014 & -0.267 \\
\hline
\end{tabular}

a Parameters with significant loadings on the within column principal component PCA - Biplot

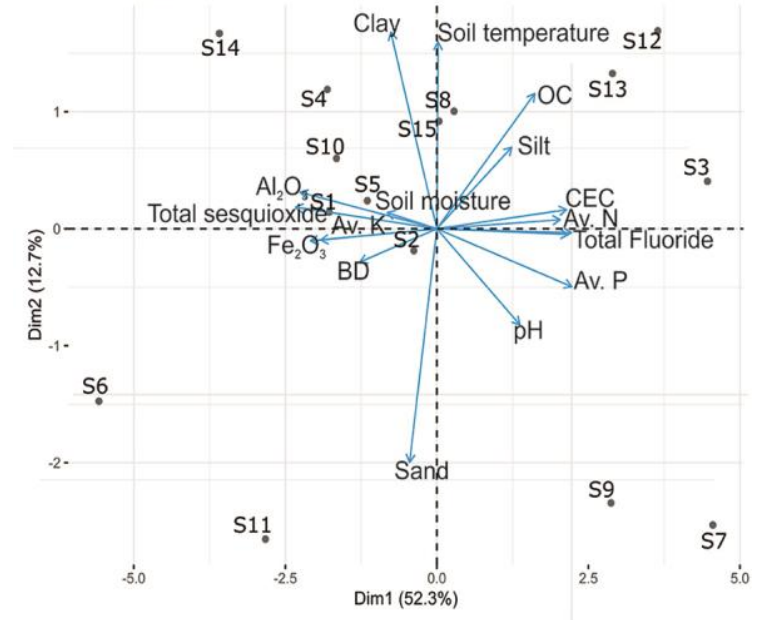

Figure 2. PCA biplot of individuals and variables. BD represent bulk density; OC, organic carbon; CEC, cation exchange capacity; Av. N, available nitrogen; Av. P, available phosphorus; Av. K, available potassium 


\section{Conclusion}

The study conducted across the wetlands of Kuttanad brought out interesting information on the heterogeneity of soil characteristics and F- concentration in soil. Similar was the case with soil nutrients (NPK), oxides of Fe and $\mathrm{Al}$ and total sesquioxides in soil. Among the soil characteristics, silt content, $\mathrm{pH}, \mathrm{EC}$, CEC. OC, $\mathrm{N}$ and $\mathrm{P}$ were identified as factors significantly contributing to the augmentation of $\mathrm{F}$ - concentration in the wetlands of Kuttanad

\section{References}

Adriano, D.C., 1986. Trace elements in the terrestrial environment. Springer-Verlag, New York. 533p.

Ahmed, S., Khalid, K., Jabeen, F., Ahmad, M.N., Zia, A., Haider, A., Mujahid, M., Zia, D., Khan, N.P., 2019. The effects of fluoride stress on okra (Abelmoschus esculentus L.). Fluoride 52: 354-361.

Annadurai, S.T., Rengasamy, J.K., Sundaram, R., Munusamy, A.P., 2014. Incidence and effects of fluoride in Indian natural ecosystem : A review. Advances in Applied Science Research 5(2): 173-185.

Baird, R.B., Eaton, A.D., Rice, E.W., 2017. Standard Methods for the Examination of Water and Wastewater, Twenty third edition. American Public Health Association, Washington DC.

Beena, V.I., 2005. Land evaluation and crop suitability rating of the acid sulphate soils of Kuttanad for sustainable land use planning. PhD Thesis. Kerala Agricultural University, Thiruvananthapuram.

Beena, V.I., Thampatti, K.C.M., 2013. Characterization of acidity in acid sulphate soils of Kerala. Journal of Life Sciences 7(8): 907-912.

Borah, J., Saikia, D., 2011. Estimation of the concentration of fluoride in the ground water of Tinsukia town master plan area of the Tinsukia district, Assam, India. Archives of Applied Science Research 3(3): 202-206.

Bustingorri, C., Lavado, R.S., 2014. Soybean as affected by high concentrations of arsenic and fluoride in irrigation water in controlled conditions. Agricultural Water Management 144: 134-139.

Chakrabarti, S., Patra, P.K., Mondal, B., 2013. Uptake of fluoride by two paddy (Oryza sativa L.) varieties treated with fluoride-contaminated water. Paddy and Water Environment 11: 619-623.

Chapman, H.D., 1965. Cation-exchange capacity, In: Methods of Soil Analysis: Part 2 Chemical and Microbiological Properties, Black, C.A., (Ed.). Wiley Online Library, pp. 891-901.

Choubisa, S.L., 2018a. Fluoride distribution in drinking groundwater in Rajasthan, India. Current Science 114(9): 18511857.

Choubisa, S.L., 2018b. A brief and critical review on hydrofluorosis in diverse species of domestic animals in India. Environmental Geochemistry and Health 40(1): 99-114.

Dharmaratne, R.W., 2019. Exploring the role of excess fluoride in chronic kidney disease. Human and Experimental Toxicology 38(3): 269-279.

Easton, Z.M., Bock, E., 2016. Soil and soil water relationships. Virginia Cooperative Extension, Virginia State University Publication BSE-194P. 9p. Available at [Access date: 15.04.2020]: https://ext.vt.edu/content/dam/ext_vt_edu/topics/agriculture/water/documents/Soil-and-Soil-WaterRelationships.pdf

Ebimol, N.L., Suresh, P.R., Binitha, N.K., Santhi, G.R., 2017. Management of iron and aluminium toxicity in acid sulphate soils of Kuttanad. International Journal of Current Microbiology and Applied Sciences 6 (11): 1496-1503.

Fuge, R., 2019. Fluorine in the environment, a review of its sources and geochemistry. Applied Geochemistry 100: 393406.

Gardner, W.H., 1986. Water content, In: Methods of Soil Analysis: Part 1 Physical and Mineralogical Methods, Klute, A., (Ed.). Wiley Online Library, pp. 493-544.

Geetha, R., Chandramohankumar, N., Mathews, L., 2007. Distribution of total reactive fluoride in sediments of Kuttanad waters. Indian Journal of Environmental Protection 27 (11): 1001-1005.

Greenwood, N.N., Earnshaw, A., 1997. Chemistry of the elements. Second edition. Elsevier. 1384p.

Gudadhe, N., Dhonde, M.B., Hirwe, N.A., 2015. Effect of integrated nutrient management on soil properties under cottonchickpea cropping sequence in vertisols of Deccan plateau of India. Indian Journal of Agricultural Research 49 (3): 207-214.

Guo, J., Hu, X., Gao, L., Xie, K., Ling, N., Shen, Q., Hu, S., Guo, S., 2017. The rice production practices of high yield and high nitrogen use efficiency in Jiangsu, China. Scientific Reports 7: 2101.

Ibia, T.O., 2005. Forms and contents of iron and aluminum in inland flood plains of South-Eastern Nigeria. Agronomie Africaine 17: 211-218.

Islam, K.R., Weil, R.R., 1998. A rapid microwave digestion method for colorimetric measurement of soil organic carbon. Communications in Soil Science and Plant Analysis 29(15-16): 2269-2284.

Jayarathne, T., Stockwell, C.E., Yokelson, R.J., Nakao, S., Stone, E.A., 2014. Emissions of fine particle fluoride from biomass burning. Environmental Science and Technology 48 (21): 12636-12644.

Jha, S.K., Mishra, V.K., Sharma, D.K., Damodaran, T., 2011. Fluoride in the environment and its metabolism in humans. In: Reviews in Environmental Contamination and Toxicology, Whitacre, D.M., (Ed.). Vol 211, Springer, pp. 121-142.

Kabir, H., Gupta, A.K., Tripathy, S., 2019. Fluoride and human health: Systematic appraisal of sources, exposures, metabolism and toxicity. Critical Reviews in Environmental Science and Technology 50 (11): 1116-1193. 
Khaledian, Y., Brevik, E.C., Pereira, P., Cerdà, A., Fattah, M.A., Tazikeh, H., 2017. Modeling soil cation exchange capacity in multiple countries. Catena 158: 194-200.

Kinnunen, H., Holopainen, T., Raisanen, L.M., Karenlampi, L., 2003. Fluoride in birch leaves, ground vegetation, litter and humus in the surrounding of a fertilizer plant and apatite mine in Silinjarvi, eastern Finland. Boreal Environment Research 8: 185-192.

Koritnig, S., 1951. Ein beitrag zur geochemie des fluor: (Mit besonderer Berücksichtigung der Sedimente). Geochimica et Cosmochimica Acta 1(2): 89-116.

Kumar, A., Mishra, V.N., Srivastav, L.K., Banwasi, R., 2014. Evaluations of soil fertility status of available major nutrients $(\mathrm{N}, \mathrm{P} \& \mathrm{~K})$ and micro nutrients (Fe, Mn, Cu \& Zn) in Vertisol of Kabeerdham District of Chhattisgarh, India. International Journal of Interdisciplinary and Multidisciplinary Studies 1 (10): 72-79.

Kumar, S., Devadas Dr., V., 2016. Integrated planning for sustainable development of Kuttanad wetland region, Kerala state. Procedia Technology 24: 1660-1667.

Lehnert, M., 2014. Factors affecting soil temperature as limits of spatial interpretation and simulation of soil temperature. AUPO Geographica 45: 5-21.

Lekwa, G., Whiteside, E.P., 1986. Coastal Plain Soils of Southeastern Nigeria: II. Forms of Extractable Iron, Aluminum, and Phosphorus. Soil Science Society of America Journal 50(1): 160-166.

Li, Y., Zhang, H., Zhang, Z., Shao, L., He, P., 2015. Treatment and resource recovery from inorganic fluoride-containing waste produced by the pesticide industry. Journal of Environmental Sciences 31: 21-29.

Loganathan, P., Hedley, M.J., Wallace, G.C., Roberts, A.H.C., 2001. Fluoride accumulation in pasture forages and soils following long-term applications of phosphorus fertilisers. Environmental Pollution 115(2): 275-282.

Lu, H., Li, J., Liu, X., Yu, Z., Lin, R., 2019. Removal of fluoride and arsenic by a hybrid constructed wetland system. Chemistry and Biodiversity 16(7): e1900078.

Mathew, E.K., Panda, R.K., Nair, M., 2001. Influence of subsurface drainage on crop production and soil quality in a lowlying acid sulphate soil. Agricultural Water Management 47(3): 191-209.

Mehra, O.P., Jackson, M.L., 1960. Iron oxide removal from soils and clays by a dithionite-citrate system buffered with sodium bicarbonate. Clays and Clay Minerals 7: 317-327.

Miller, W.P., Miller, D.M., 1987. A micro-pipette method for soil mechanical analysis. Communications in Soil Science and Plant Analysis 18(1): 1-15.

Mondal, N.K., 2017. Effect of fluoride on photosynthesis, growth and accumulation of four widely cultivated rice (Oryza sativa L.) varieties in India. Ecotoxicology and Environmental Safety 144: 36-44.

Mondal, N.K., Pal, K.C., Dey, M., Ghosh, S., Das, C., Datta, J.K., 2015. Seasonal variation of soil enzymes in areas of fluoride stress in Birbhum District, West Bengal, India. Journal of Taibah University for Science 9(2): 133-142.

Naik, R.G., Dodamani, A.S., Vishwakarma, P., Jadhav, H.C., Khairnar, M.R., Deshmukh, M.A., Wadgave, U., 2017. Level of fluoride in soil, grain and water in Jalgaon district, Maharashtra, India. Journal of Clinical and Diagnostic Research 11: ZC05-ZC07.

Nunes, M.R., Denardin, J.E., Pauletto, E.A., Faganello, A., Pinto, L.F.S., 2015. Mitigation of clayey soil compaction managed under no-tillage. Soil and Tillage Research 148: 119-126.

Owolabi, O., Adeleye, A., Oladejo, B.T., Ojeniyi, S.O., 2003. Effect of wood ash on soil fertility and crop yield in Southwest Nigeria. Nigerian Journal of Soil Science 13: 55-60.

Ozsvath, D.L., 2009. Fluoride and environmental health: a review. Reviews in Environmental Science and Bio/Technology 8 (1): 59-79.

Panchal, L., Sheikh, Z., 2017. Dental fluorosis in domesticated animals in and around Umarda village of Udaipur, Rajasthan, India. Haya: The Saudi Journal of Life Sciences 2(7): 248-254.

Pettinati, M., Perrin, J., Pauwels, H., Ahmed, S., 2013. Simulating fluoride evolution in groundwater using a reactive multicomponent transient transport model: Application to a crystalline aquifer of Southern India. Applied Geochemistry 29: 102-116.

Pyngrope, D., Mithare, P., Ghosh, G., 2019. Influence of different planting system and levels of nitrogen on growth, yield, quality and economics of rice (Oryza sativa L.) - A review. International Journal of Current Microbiology and Applied Sciences 8(1): 2161-2172.

Qiao, W., Xie, Z., Zhang, Y., Lu, X., Xie, S., Huang, J., Yu, L., 2018. Perfluoroalkyl substances (PFASs) influence the structure and function of soil bacterial community: Greenhouse experiment. Science of the Total Environment 642: 11181126.

Raj, D., Shaji, E., 2017. Fluoride contamination in groundwater resources of Alleppey, southern India. Geoscience Frontiers 8(1): 117-124.

R Core Team., 2019. R: A language and environment for statistical computing. R Foundation for statistical computing. Vienna, Austria.

Ropelewska, E., Dziejowski, J., Zapotoczny, P., 2016. Changes in the microbial activity and thermal properties of soil treated with sodium fluoride. Applied Soil Ecology 98: 159-65.

Saidi, D., 2012. Importance and role of cation exchange capacity on the physicals properties of the Cheliff saline soils (Algeria). Procedia Engineering 33: 435-449. 
Sarkar, R.K., Chakraborty, K., Chattopadhyay, K., Ray, S., Panda, D., Ismail, A., 2019. Responses of rice to individual and combined stresses of flooding and salinity. In: Advances in Rice Research for Abiotic Stress Tolerance, Hasanuzzaman, M., Fujita, M., Nahar, K., Biswas, J., (Eds.). Woodhead publishing, pp. 281-297.

Shaw, J.W., West, L.T., 2017. Sesquioxides In: Encyclopedia of Soil Science. Lal, R. (Ed.). Third edition. CRC Press, Boca Raton.

Singh, G., Kumari, B., Sinam, G., Kumar, N., Mallick, S., 2018. Fluoride distribution and contamination in the water, soil and plants continuum and its remedial technologies, an Indian perspective- a review. Environmental Pollution 239: 95-108.

Skjelkvåle, B.L., 1994. Factors influencing fluoride concentrations in Norwegian lakes. Water, Air, and Soil Pollution 77: 151-167.

Smolik, B., Telesiński, A., Szymczak, J., Zakrzewska, H., 2011. Assessing of humus usefulness in limiting of soluble fluoride content in soil. Ochrona Środowiska i Zasobów Naturalnych 49: 202-208.

Standfold, S., English, S., 1949. Use of the flame photometer in rapid soil tests for K and Ca. Agronomy Journal 141(9): 446-447.

Subbaiah, B.V., Asija, G.L., 1956. A rapid procedure for estimation of available nitrogen in soil. Current Science 25(8): 259-260.

Suganya, K., Sivapullaiah, P.V., 2015. Effect of changing water content on the properties of Kuttanad soil. Geotechnical and Geological Engineering 33: 913-921.

Taylor, H., Brar, G.S., 1991. Effect of soil compaction on root development. Soil and Tillage Research 19(2-3): 111-119.

Telesiński, A., Musik, D., Smolik, B., Klódka, D., Śnioszek, M., Szymczak, J., Grabcyńska, E., 2008. An attempt to determine the correlation between enzymatic activity and fluorine content in forest soils affected by emission from Police chemical plant I, In: Ecotoxicology in environmental Protection, Kolwzan, B., Grabas, K., (Eds.). Wroclaw-Wyd Politech Wroc, pp 421-426. [in Polish]

Thafna, K.K., Navya, C., Binish, M.B., Gopikrishna, V.G., Mahesh, M., 2017. Distribution of nutrients in the soils of a unique tropical agroecosystem. Environmental Pollution and Protection 2(2): 56-65.

Thampatti, K.C.M., Jose, A.I., 2000. Characterization of acid saline rice based wetland ecosystems of Kuttanad , Kerala , and their salinity protection by Thanneermukkom regulator. Agropedology 10: 111-115.

Tsai, W.H., 2010. Environmental and health risks of sulfuryl fluoride, a fumigant replacement for methyl bromide. Journal of Environmental Science and Health, Part C, 28 (2): 125-145.

Tyagi, R., Luhach, J., Mishra, A.K., Chaudhry, S., 2017. Morphological and biochemical changes in Vigna radiata and Spinacia oleracea induced by fluoride contamination in soils. International Journal of Current Microbiology and Applied Sciences 6(5): 395-402.

Underwood, E.J, 1977. Trace elements in human and animal nutrition. Fourth edition. Academic Press. 545p.

Unger, P.W., Kaspar, T.C., 1994. Soil compaction and root growth: A Review. Agronomy Journal 86(5): 759-766.

Varma, A., 2017. Groundwater resource and governance in Kerala: Status, issues and prospects. Forum for Policy Dialogue on Water Conflicts in India. 104p.

Watanabe, F.S., Olsen, S.R., 1965. Test of an Ascorbic Acid Method for determining phosphorus in water and NaHC03 extracts from soil. Soil Science Society of America Journal 29(6): 677-678.

Xie, Z., Li, J., Wu, W., 2008. Application of GIS and Geostatistics to Characterize Spatial Variation of Soil Fluoride on Hang-Jia-Hu Plain, China, In: Computer And Computing Technologies In Agriculture, Volume I. CCTA 2007, Li, D., (Ed.). Vol 258, The International Federation for Information Processing, Springer, Boston, MA.

Yuan, J., Li, Q., Niu, R., Wang, J., 2019. Fluoride exposure decreased learning ability and the expressions of the insulin receptor in male mouse hippocampus and olfactory bulb. Chemosphere 224: 71-76. 